\title{
Phenylcarbamic acid derivatives with integrated n-phenylpiperazine moiety in the structure - kinetics of alkaline hydrolysis study Deriváty kyseliny fenylkarbámovej s integrovanou n-fenylpiperazínovou zložkou v štruktúre - štúdium kinetiky alkalickej hydrolýzy
}

\begin{abstract}
In present work, we have studied kinetics of alkaline hydrolysis of 14 compounds, which are phenylcarbamic acid derivatives with integrated $\mathrm{N}$-phenylpiperazine moiety in the structure. The compounds possessed moderate antiarrhythmic and antimycobacterial activity. Their hydrolysis was carried out in an aqueous medium ethanol sodium hydroxide solution. The course of the hydrolysis was observed spectrophotometrically in visible as well as in ultraviolet regions. The pseudo-first order rate constants were calculated at several temperatures. The values of the activation energy $E_{A}$ were determined by the Arrhenius equation. The rate of hydrolysis of the compounds under the study increase with the increase in temperature and it has been differentiated according to the substitution of $N$-phenylpiperazine as well as to the alkoxy substitution on phenyl ring.

Slovak V predloženej práci smeštudovali kinetikualkalickej hydrolýzy štrnástich látok, derivátov kyseliny fenylkarbámovej s integrovanou abstract $N$-phenylpiperazínovou zložkou v štruktúre. Látky majú mierny antiarytmický a antituberkulózny účinok. Hydrolýza prebiehala vo vodno-etanolovom roztoku hydroxide sodného. Priebeh hydrolýzy sme sledovali pomocou spektrofotometrie vo viditelinej ako aj v ultrafialove oblasti. Stanovili sme rýchlostné konstanty pseudo-prvého poriadku pri viacerých teplotách. Hodnoty aktivačnej energie $E_{A}$ boli vypočítané pomocou Arrheniovej rovnice. Rýchlost' hydrolýzy študovaných látok rástla so zvyšovaním teploty a lišila sa v závislosti od substitúcie $N$-fenylpiperazín, ako aj od alkoxy substitúcie na benzénovom kruhu.
\end{abstract}

Keywords Phenylcarbamic acid derivatives - Alkaline hydrolysis - Chemical kinetics - Antiarrhythmics - Stability

Klúčové Deriváty kyseliny fenylkarbámovej-alkalická hydrolýza-chemická kinetika-antiarytmiká-stabilita slová:

\section{INTRODUCTION}

The derivatives of ortho-, meta- and paraalkoxyphenylcarbamic acids containing substituted $N$-phenylpiperazin-1-yl fragment within their structure have been originally synthesised as potential antiarrhythmic drugs by Malík et al. (2004, 2005, 2006). These new compounds have also shown weak antimycobacterial activity, as Waisser et al. (2007) has previously observed. During the study of their physicochemical properties, the melting points, solubility, surface activity, dissociation constants and some lipophilicity parameters, i.e. partition coefficients, retention factors from $\mathrm{RP}-\mathrm{HPLC}$ and $R_{\mathrm{M}}$ values from RP-TLC were determined by Malík et al. $(2005,2006)$. Except for experimental determination of the partition coefficient readouts, several different computer programs employing different calculation methods for the lipophilicity parameters prediction of prepared compounds were used by Malík et al. (2006). The inspected molecules (Table 1 ), because of being esters, may easily undergo hydrolysis, which is, in addition to oxidation, is the most frequent cause of chemical instability of the drugs. The results of the kinetics of hydrolysis of these compounds provide the fundamental reason for their stability. The kinetics of the reaction may be calculated from the rate constants and the activation

*E-mail: stankovicm@fpharm.uniba.sk

( ) Acta Facultatis Pharmaceuticae Universitatis Comenianae 
parameters, i.e. activation energy $E_{\mathrm{A}}$ determined from temperature dependence of the rate constants. Following the evaluation of complex physicochemical properties of basic esters, the aim of this work is the study of kinetics of their alkaline hydrolysis. In terms of fundamental structural aspects, the influence of alkoxy side chain attached to phenyl ring as well as the substitution on $N$-phenylpiperazin-1-yl moiety within the structure on the stability is evaluated.

\section{MATERIALS AND METHODS}

\section{Studied compounds}

The investigated molecules were synthesized by Malík et al. $(2004,2005)$ and their general chemical structure is shown in Table 1. All other chemicals and solvents used were analytical grade.

Table 1. General chemical structure of studied compounds

\begin{tabular}{|c|c|c|c|}
\hline Compound & $R^{1}$ & $R^{2}$ & $M_{r}$ \\
\hline $5 d$ & $3-\mathrm{OCH}_{3}$ & $2^{\prime}-\mathrm{F}$ & 439.91 \\
\hline $5 e$ & $3-\mathrm{OC}_{2} \mathrm{H}_{5}$ & $2^{\prime}-F$ & 453.94 \\
\hline $6 a$ & $2-\mathrm{OCH}_{3}$ & $4^{\prime}-\mathrm{F}$ & 439.91 \\
\hline $6 b$ & $2-\mathrm{OC}_{2} \mathrm{H}_{5}$ & $4^{\prime}-\mathrm{F}$ & 453.94 \\
\hline $6 d$ & $3-\mathrm{OCH}_{3}$ & $4^{\prime}-\mathrm{F}$ & 439.91 \\
\hline $6 e$ & $3-\mathrm{OC}_{2} \mathrm{H}_{5}$ & $4^{\prime}-F$ & 453.94 \\
\hline $6 i$ & $4-\mathrm{OCH}_{3}$ & $4^{\prime}-\mathrm{F}$ & 439.91 \\
\hline 61 & $4-\mathrm{OC}_{4} \mathrm{H}_{9}$ & $4^{\prime}-\mathrm{F}$ & 481.99 \\
\hline $8 a$ & $2-\mathrm{OCH}_{3}$ & $3^{\prime}-\mathrm{CF}_{3}$ & 489.92 \\
\hline $8 b$ & $2-\mathrm{OC}_{2} \mathrm{H}_{5}$ & $3^{\prime}-\mathrm{CF}_{3}$ & 503.95 \\
\hline $8 c$ & $3-\mathrm{OCH}_{3}$ & $3^{\prime}-\mathrm{CF}_{3}$ & 489.92 \\
\hline $8 d$ & $3-\mathrm{OC}_{2} \mathrm{H}_{5}$ & $3^{\prime}-\mathrm{CF}_{3}$ & 503.95 \\
\hline $8 f$ & $4-\mathrm{OCH}_{3}$ & $3^{\prime}-\mathrm{CF}_{3}$ & 489.92 \\
\hline $8 g$ & $4-\mathrm{OC}_{2} \mathrm{H}_{5}$ & $3^{\prime}-\mathrm{CF}_{3}$ & 503.95 \\
\hline
\end{tabular}

\section{Apparatus}

Ultra thermostat Memmert WB 10, (Germany), a diode array spectrophotometer Vectra 8452 (Hewlett Packard, USA), spectrophotometer Spectronic 20 D (Milton Roy, USA) were used for the measurements. The hydrolysis of studied substances was carried out in aqueous-ethanol sodium hydroxide solution $0.1 \mathrm{~mol} \mathrm{dm}^{-3}$ in closed flasks tempered in thermostat at several temperatures, e.g. $45.0 \pm 0.5^{\circ} \mathrm{C}, 50.0$ $\pm 0.5^{\circ} \mathrm{C}, 55.0 \pm 0.5^{\circ} \mathrm{C}, 60.0 \pm 0.5^{\circ} \mathrm{C}, 65.0 \pm 0.5^{\circ} \mathrm{C}$ and $70.0 \pm$ $0.5^{\circ} \mathrm{C}$, respectively. The ethanol concentration was $50 \%(\mathrm{v} / \mathrm{v})$, the concentration of studied substances was $4^{\prime} 10^{-5} \mathrm{~mol} \mathrm{dm}^{-3}$.
The concentration of corresponding aniline produced by the reaction was determined spectrophotometrically in the visible region using the diazotization reaction with sodium nitrite and copulation with 2 naphthole. The processing method has been previously described in Stankovičová et al. (1975). The hydrolysis rate of the compounds labelled as $8 \mathrm{a}, 8 \mathrm{~b}, 8 \mathrm{f}$ and $8 \mathrm{~g}$ was determined spectrophotometrically in the UV region by the method described in Stankovičová et al. (1978).

\section{Calculations}

The rate constants of the alkaline hydrolysis were calculated using the kinetic equation of the pseudo-first order described in Treindl (1990):

$\ln (a-x)=\ln a-k t$

where $k$ is the pseudo-first order rate constant, $a$ is the starting concentration of studied substance, $x$ is the concentration of substituted aniline, the product of decomposition. The Arrhenius activation energy $E_{\mathrm{A}}$ values in Table 2 were derived by a least square analysis of plots of log $k$ against $1 / T$. The values $E_{A}$ in Table 3 are calculated from the two values of rate constants:

$$
E_{A}=\frac{2.303 \times R \times T_{1} \times T_{2}}{T_{1}-T_{2}} \log \frac{k_{1}}{k_{2}},
$$

where $R$ is the molar gas constant, $T$ is the thermodynamic temperature and $E_{\mathrm{A}}$ the activation energy (Treindl 1990).

\section{RESULTS AND DISCUSSION}

The kinetics of alkaline hydrolysis of the compounds $5 \mathrm{~d}-$ $8 \mathrm{~g}$, chemically 1-(2'-fluorophenyl)-, 1-(4'-fluorophenyl)-, and 1-(3'-trifluoromethylphenyl)-4-[3-(2-/3-4-alkoxyphenylcarbamoyloxy)-2-hydroxypropan-1-yl]piperazinium chlorides, was studied in this paper. The compounds contain alkoxy side chain with one to four carbon atoms attached to aromatic ring and, additionally, they differ in their basic character. It has been previously observed that the substances under the study possessed weak antiarrhythmic and moderate antimycobacterial activity. Their solubility in water is very limited and that is the reason for using ethanol in the reaction medium. In general, the derivatives of phenylcarbamic acid in alkaline medium undergo hydrolysis. They are decomposed to final products - substituted derivative of aniline, basic alcohol, in this case 3-(4-phenylpiperazin-1-yl)propan-1,2diol, and carbon dioxide, as drawn in Fig. 1.

The goal of present paper is to evaluate the influence of described variations within the chemical structure of inspected molecules on the alkaline hydrolysis rate. First, we observed the kinetics of hydrolysis of such compounds containing a 
Table 2. Experimental values of rate constants $k$ of hydrolysis in aqueous - ethanol sodium hydroxide solution $0.1 \mathrm{~mol} / \mathrm{l}$ and values of activation energy $E_{A}$ of the set $5 d-61$

\begin{tabular}{|c|c|c|c|c|c|}
\hline \multirow{2}{*}{ Compound } & \multicolumn{4}{|c|}{$k^{\prime} 10^{5}\left[s^{-1}\right]$} & \multirow{2}{*}{$\begin{array}{c}E_{A} \\
{\left[\mathrm{~kJ} \mathrm{~mol}^{-1}\right]}\end{array}$} \\
\hline & $55.0^{\circ} \mathrm{C}$ & $60.0^{\circ} \mathrm{C}$ & $65^{\circ} \mathrm{C}$ & $70.0^{\circ} \mathrm{C}$ & \\
\hline $5 d$ & $1.678 \pm 0.150$ & $2.189 \pm 0.086$ & $2.400 \pm 0.078$ & $2.667 \pm 0.103$ & $27.8 \pm 1.5$ \\
\hline $5 e$ & $1.489 \pm 0.067$ & $1.994 \pm 0.092$ & $2.267 \pm 0.100$ & $2.575 \pm 0.083$ & $35.9 \pm 2.0$ \\
\hline $6 a$ & $1.911 \pm 0.114$ & $2.478 \pm 0.175$ & $2.872 \pm 0.108$ & $3.644 \pm 0.219$ & $39.6 \pm 2.0$ \\
\hline $6 b$ & $1.920 \pm 0.092$ & $2.300 \pm 0.114$ & $3.256 \pm 0.186$ & $4.158 \pm 0.189$ & $49.6 \pm 2.6$ \\
\hline $6 d$ & $2.178 \pm 0.096$ & $2.406 \pm 0.094$ & $2.614 \pm 0.111$ & $3.514 \pm 0.078$ & $28.3 \pm 6.8$ \\
\hline $6 e$ & $2.064 \pm 0.161$ & $2.181 \pm 0.119$ & $2.433 \pm 0.081$ & $2.754 \pm 0.078$ & $28.7 \pm 5.0$ \\
\hline $6 i$ & $1.475 \pm 0.061$ & $1.894 \pm 0.068$ & $2.400 \pm 0.119$ & $2.772 \pm 0.097$ & $44.6 \pm 0.3$ \\
\hline 61 & $1.753 \pm 0.069$ & $2.139 \pm 0.114$ & $2.836 \pm 0.164$ & $3.322 \pm 0.150$ & $38.6 \pm 2.5$ \\
\hline
\end{tabular}<smiles>[R]c1cccc(NC(=O)OCC(O)CN2CCN(c3cccc(CC)c3)CC2)c1</smiles>

Figure 1. The course of alkaline hydrolysis of the studied compounds

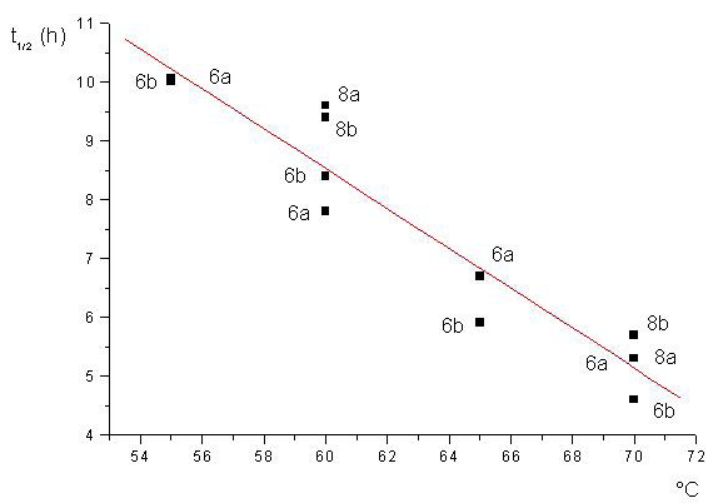

Figure 2. The plot of $t_{1 / 2}$ of hydrolysis rate against temperature for ortho-alkoxy substituted derivatives

fluorine atom attached to $2^{\prime}$ or $4^{\prime}$ position on the aromatic ring. The course of their hydrolysis was observed by applying the spectrophotometry in the visible region. The calculated values of rate constants of alkaline hydrolysis are listed in the Table 2. The rate is influenced by the length of the alkoxy substituent, by its positional isomerism on phenyl ring as well as by the character of substitution on $N$-phenylpiperazin-1-yl moiety. The influence of different substituents of ortho-alkoxy substituted compounds on hydrolysis rate is demonstrated in Fig. 2 where the half-life $t_{1 / 2}$ vs temperature is plotted. The compounds $6 \mathrm{a}$ and $6 \mathrm{~b}$ containing a fluorine atom attached to para-position are hydrolysed more quickly at both temperatures $60^{\circ} \mathrm{C}$ and $70^{\circ} \mathrm{C}$ than the compounds $8 \mathrm{a}$ and $8 \mathrm{~b}$ bearing meta-trifluoromethyl group.
In Table 3, the values of the estimated rate constants are determined by spectrophotometry in the UV region for compounds in the series 8. Compared to the previously evaluated set $5 d-61$, the rate of hydrolysis of the investigated molecules $8 \mathrm{a}-8 \mathrm{~g}$ is also influenced by the substitution within basic part as well as by the position of the presence of the alkoxy group on the side chain.

The values of half-lives vs temperature of meta-alkoxy substituted compounds are depicted in Fig. 3. The molecules $6 \mathrm{~d}$ and $6 \mathrm{e}$ are hydrolysed more quickly than the ones containing 2'-fluoro substituent, $5 \mathrm{~d}$ and $5 \mathrm{e}$. The slowest rate of the hydrolysis is observed at $60{ }^{\circ} \mathrm{C}$ for the compounds $8 \mathrm{~d}$ and $8 \mathrm{c}$. The values of determined half-lives of meta-akoxy substituted substances are closer at higher temperature than at the lower one. At temperatures $55.0^{\circ} \mathrm{C}$ and at $60.0^{\circ} \mathrm{C}$, the values of the rate constants are more differentiated and the influence of various substitution is more obvious.

Fig. 4 shows the readouts related to para-alkoxy substituted compounds, their half-lives of the rate of hydrolysis against the temperature. The molecules $8 f$ and $8 \mathrm{~g}$ are hydrolysed more quickly than those with 4'-fluoro moiety, $6 \mathrm{i}$ and $6 \mathrm{I}$. This is different in terms of previous findings where the substances bearing 3'-trifluoromethyl have shown higher values of rate constants. The explanation is possible in order to negative value of electronic substituent constants $\sigma_{p}$ of single fluorine atom attached to the phenyl ring versus the positive value of electronic constant $\sigma_{\mathrm{m}}$ related to 3'-trifluoromethyl group. These substituent constants have been previously published by Hansch et al. (1973). They lead to the elevation of the hydrolytic reaction rate. In Table 4 the coefficients of the plots $\mathrm{t}_{1 / 2}$ against temperature is shown. 
Phenylcarbamic acid derivatives with integrated n-phenylpiperazine moiety in the..

Table 3. Experimental values of rate constants k of hydrolysis in aqueous-ethanol sodium hydroxide solution 0.1 mol// and calculated values of activation energy $E_{A}$ of the set $8 a-8 g$

\begin{tabular}{|c|c|c|c|}
\hline \multirow{2}{*}{ Compound } & \multicolumn{2}{|c|}{$k^{\prime} 10^{5}\left[s^{-1}\right]$} & \multirow{2}{*}{$\begin{array}{c}E_{A} \\
{\left[\mathrm{~kJ} \mathrm{~mol}^{-1}\right]}\end{array}$} \\
\hline & $60.0^{\circ} \mathrm{C}$ & $70.0^{\circ} \mathrm{C}$ & \\
\hline $8 a$ & $2.012 \pm 0.103$ & $3.628 \pm 0.170$ & $56.1 \pm 1.8$ \\
\hline $8 b$ & $2.054 \pm 0.070$ & $3.378 \pm 0.182$ & $47.3 \pm 1.7$ \\
\hline $8 c$ & $1.983 \pm 0.165$ & $3.161 \pm 0.133$ & $44.3 \pm 2.5$ \\
\hline $8 d$ & $1.628 \pm 0.033$ & $2.883 \pm 0.146$ & $54.3 \pm 1.4$ \\
\hline $8 f$ & $2.371 \pm 0.115$ & $4.449 \pm 0.291$ & $59.8 \pm 2.1$ \\
\hline $8 g$ & $2.044 \pm 0.094$ & $3.614 \pm 0.294$ & $54.1 \pm 2.5$ \\
\hline
\end{tabular}

Table 4. Coefficients of linear equation $t_{1 / 2}$ versus temperature

\begin{tabular}{|c|c|c|c|c|c|c|}
\hline Derivatives & $\boldsymbol{n}$ & $\boldsymbol{r}$ & $\boldsymbol{s}$ & $\boldsymbol{F}$ & $\boldsymbol{a}_{\mathbf{0}}$ & $\boldsymbol{a}_{\mathbf{1}}$ \\
\hline ortho & 12 & -0.9551 & 0.6370 & 103.9 & 28.89 & -0.3393 \\
\hline meta & 20 & -0.8122 & 1.1378 & 34.89 & 25.46 & -0.2685 \\
\hline para & 12 & -0.9285 & 0.9891 & 62.52 & 34.03 & -0.4085 \\
\hline
\end{tabular}

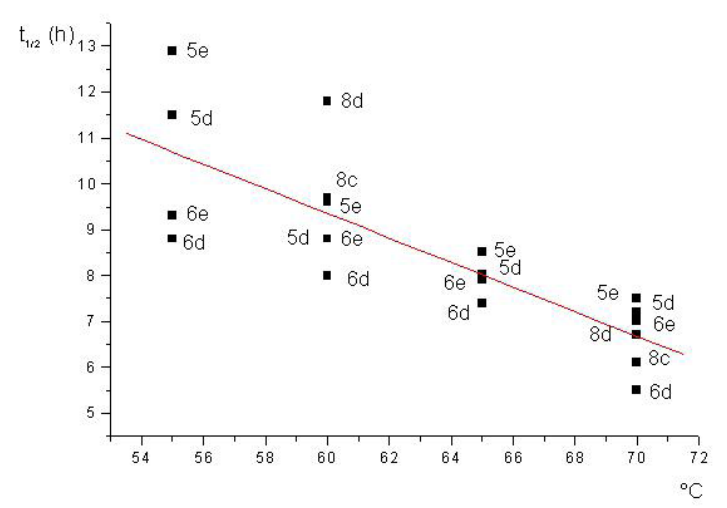

Figure 3. The plot of $t_{1 / 2}$ of hydrolysis rate against temperature for meta-alkoxy substituted derivatives

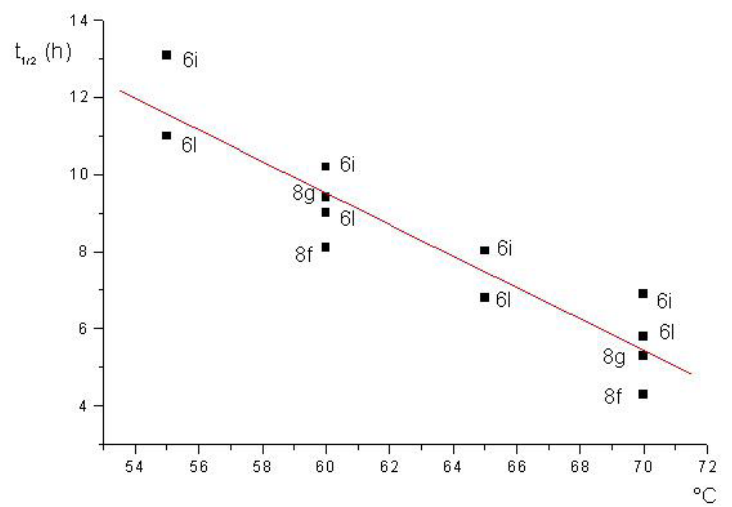

Figure 4. The plot of $t_{1 / 2}$ of hydrolysis rate against temperature for para-alkoxy substituted derivatives
The values of activation energies are derived by a leastsquares analysis of plots of log $k$ against $1 / T$ or they can be calculated from the two values of rate constants. The most predictive kinetic procedures for the evaluation of stability are based on the Arrhenius equation, which expresses the temperature dependence of rate constant. The straight line obtained by this plot can be extrapolated to the temperature of storage of compound and the corresponding value of log $k$ can be determined. However, the methods for determining the expiration date, which are based on the Arrhenius law, are valid only when decomposition is a thermal process and the order of magnitude of the activation energy is 42 to $126 \mathrm{~kJ} /$ mol. According to Rácz (1989), when the Arrhenius equation is applied to the overall rate complex reactions, it becomes increasingly difficult to make an accurate stability prediction. The proposed reaction mechanism of the alkaline hydrolysis of aromatic carbamate by Dittert et al. (1963) assumes the formation of isocyanate as an intermediate in the second step of the reaction. The isocyanate is then decomposed to the derivative of aniline and carbon dioxide, so the process of decomposition of phenylcarbamic acid-based compounds is complex. The values of activation energy of these structures, summarized in the Table 3, are higher than the outputs in Table 2 where are the values $E_{\mathrm{A}}$ of the compounds bearing $2^{\prime}$-fluoro or 4'-fluoro moiety within basic compartment. The values of $E_{\mathrm{A}}$ of the derivatives with integrated $N$-phenylpiperazine moiety in the structure are lower compared to the ones determined by Stankovičová et al. $(1987,2009)$ under the same experimental conditions. The structure of currently analysed compounds is more complex than those studied earlier so presently investigated derivatives can be regarded as less stable. The higher activation energy, the more the reaction is hindered. 


\section{CONCLUSION}

The hydrolysis rate of the compounds under study was differentiated according to the substituent attached to $\mathrm{N}$-phenylpiperazine as well as the positional isomerism of the alkoxy side chain. The hydrolysis of such derivatives containing alkoxy group in the ortho-, meta- or para-position is influenced by an induction effect. The presence of alkoxy substituent in the ortho- or in para-position leads to an increase in the electron density of the carbamate functional group. For this reason, the reactivity of such derivatives with the hydroxyl ion decreases. On the other hand, the secondary steric effect of alkoxy substituent in the ortho-position reduces the induction effect. The fluorine atom attached to the phenyl ring in the $2^{\prime}$ as well as in $4^{\prime}$-position and the presence of trifluoromethyl moiety in $3^{\prime}$-position manifested in a negative induction effect. The hydrolysis at $70^{\circ} \mathrm{C}$ proceeds more rapidly for the compounds bearing ortho-ethoxy and para-ethoxy side chain with a simultaneous presence of 3'-trifluoromethyl or 4'-fluoro groups integrated within basic part. The rate of hydrolysis increases with the increase in temperature.

\section{References}

[1] Dittert, L. W., \& Higuchi, T. Rates of hydrolysis of carbamate and carbonate esters in alkaline solution. Journal of Pharmaceutical Sciences 1963; 52: 852.

[2] Hansch, C., Leo, A., Unger, S. H., Ki Hwan Kim, Nikaitani, D., \& Lien, E. J. Aromatic" substituent constants for structure-activity correlations. Journal of Medicinal Chemistry 1973; 16: 1207-1216.

[3] Malík, I., Sedlárová, E., Csöllei, J., Račanská, E., Čižmárik, J. \& Kurfürst, P. Synthesis, physico-chemical properties and biological activity of 1-(4-fluorophenyl)-4-[3-(2-, 3- and 4-alkyloxyphenylcarbamoyloxy)-2-hydroxypropyl]piperazinium chlorides. Scientia Pharmaceutica 2004; 72: 283-291.

[4] Malík, l., Sedlárová, E., Andriamainty, F., \& Csöllei, J. A study of physicochemical properties of 2-, 3-, 4-alkoxyphenylcarbamic acid derivatives with a substituted $\mathrm{N}$-phenylpiperazine moiety in basic part. (In Slovak) Česká a slovenská farmacie, Czech and Slovak Pharmacy 2005; 54: 235-239.

[5] Malík, I., Sedlárová, E., Csöllei, J., Andriamainty, F., Kurfürst, P., \& Vančo, J. (). Synthesis, spectral description, and lipophilicity parameters determination of phenylcarbamic acid derivatives with integrated $\mathrm{N}$-phenylpiperazine moiety in structure. Chemical Papers 2006; 60: 42-47.

[6] Rácz, I. Drug Formulation. Budapest, Akadémiai Kiadó, 1989; p. 95-104.

[7] Stankovičová, M., Kučárová, M., \& Pešák, M. Kinetics of alkaline hydrolysis of substituted esters of phenylcarbamic acid. Chemical Papers 1975; 29: 227-233.
[8] Stankovičová, M., Čižmárik, J., \& Pešák, M. Kinetics of alkaline hydrolysis of the 2-piperidinoethyl esters of $\mathrm{O}-, \mathrm{m}-$, and p-alkoxyphenylcarbamic acid. Chemical Papers 1978; 32: 86-91.

[9] Stankovičová, M., Bachratá, M., Bezáková, Ž., Blešová, M., Čižmárik, J., \& Borovanský, A. Studies of local anaesthetics, LXXXVI. Study of the kinetics of alkaline hydrolysis of carbisocainium chloride, pentacainium chloride and heptacainium chloride. (In Slovak). Česká a slovenská farmacie, Czech and Slovak Pharmacy 1987; 36: 9-15.

[10] Stankovičová, M., Bezáková, Ž., Lukášová-Masná, P., \& Lukáš, L. Kinetics of alkaline hydrolysis of potential local anaesthetics - the basic esters of phenylcarbamic acids. Acta Facultatis Pharmaceuticae Universitatis Comenianae 2009; 56: 128-135.

[11] Treindl, L'. Chemická kinetika, Chemical Kinetics (in Slovak). Bratislava, Slovak Pedagogical Publishing House, 2nd. ed., 1990; p. 21-22, 73. ISBN 80-08-00365-0.

[12] Waisser, K., Doležal, R., Čižmárik, J., Malík, I., \& Kaustová, J. The antimycobacterial derivatives against potential pathogenic strains: 2-Hydroxy-3-(4-phenylpiperazin-1-yl)propylphenylcarbamates. Scientia Pharmaceutica 2007; 75: 55-61. 